\title{
Public Space Update. Report from the United States
}

\author{
Margaret Crawford \\ University of California Berkeley, USA \\ College of Environmental Design \\ mcrawfor@berkeley.edu
}

\begin{abstract}
Like everything else in this large and disparate country, public space, as a movement and as a collection of physical places is highly varied and unequally distributed. Even so, over the last decade public space in both senses has moved to the forefront of American urbanism. In terms of academic debates, the narratives of decline that dominated discussions of public space since the 1990s have been replaced with expanded definitions of public space. The number of actual new public spaces, public events and support for them has grown exponentially over the last decade. These spaces continue to attract large numbers of people. For design professionals, this has meant new opportunities to connect their practices with the larger public realm. At the same time, however, critics have raised important questions about their inclusivity and ability to promote genuine social interaction.
\end{abstract}

Keywords: Public Space; United States; New Urbanism; Occupy Movement; Black Lives Matter.

\section{To cite this article:}

Crawford, M. (2016). Public Space Update. Report from the United States. The Journal of Public Space, I(I), II-I6, DOI: I0.5204/jps.vliI.5

This article has been peer-reviewed and accepted for publication in The Journal of Public Space. Please see the Editorial Policies under the 'About' section of the journal website for further information.

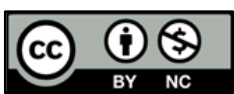

This work is licensed under a Creative Commons Attribution - Non Commercial 4.0 International License. https://creativecommons.org/licenses/by-nc/4.0/ 


\section{Introduction}

Like everything else in this large and disparate country, public space, as a movement and as a collection of physical places is highly varied and unequally distributed. Even so, over the last decade public space in both senses has moved to the forefront of American urbanism. In terms of academic debates, the narratives of decline that dominated discussions of public space since the 1990s have been replaced with expanded definitions of public space. The number of actual new public spaces, public events and support for them has grown exponentially over the last decade. These spaces continue to attract large numbers of people. For design professionals, this has meant new opportunities to connect their practices with the larger public realm. At the same time, however, critics have raised important questions about their inclusivity and ability to promote genuine social interaction.

In order to understand both the conceptual and the physical dimensions of public space, we need to clarify what public space is. Until recently, theorists held to a very pure notion of public space. Drawing a firm line between public and private, they argued that only spaces that were open to everyone and collectively owned (usually through the state) were "true" public spaces'. Current definitions of public space have become more expansive and nuanced, recognizing their multiplicity and complexity. This acknowledges public spaces where public and private are blurred, such as "quasi-public" spaces such as shopping malls, or semi-public spaces such as POPS (privately owned public spaces) which are usually corporately sponsored plazas, the best known of which is Zuccotti Park in Lower Manhattan, where the Occupy Movement began. There are also publically owned, but privately managed (usually by non-profit organizations) spaces such as Central Park, funded and supervised by the Central Park Conservancy.

The migration of much political debate on-line to virtual public spaces has helped clarify the differences between the public sphere of civic engagement (an arena of debate and discussion) and physical spaces whose civic benefits are still being debated. In a nation without a long tradition of the commons and spaces historically associated with collective use, no universal model of public space has emerged. Continuous influxes of immigrants from around the globe, whose experiences of public space vary widely, insure that the meanings of public space will remain in flux, as new uses and demands continue to reshape society and space.

\section{New Landscapes of Public Space}

In spite of these complications, we can identify a broad array of organizations, people, activities, events, times and places that have recently come together to create and constitute contemporary public spaces in the U.S. Although the General Services Administration, which manages federal properties, issued a guide urging "great federal public spaces", and the National Endowment for the Arts funds Creative Placemaking, individual cities have taken the lead in supporting, producing and maintaining public spaces $^{2}$. Their efforts vary widely according to city size budget and, most importantly, the commitment of the mayor and city officials. One of the most notable and best-publicized efforts was that of Michael Bloomberg, mayor of New York from 2001 to 2014. His planning director, Amanda Burden, a former employee of William $\mathrm{H}$. Whyte and who claimed Jane Jacobs as her greatest influence, constantly emphasized the importance of 
public space ${ }^{3}$. Burden was instrumental in producing not only highly designed places such as the High Line and Brooklyn Bridge Park, but also the lower Manhattan and Brooklyn waterfronts, as well as upgrading smaller urban plazas such as Madison Square Park and Union Square. Similarly, Bloomberg's Transportation Commissioner, Janette Sadik-Khan, implemented a dramatic pedestrianization of city streets, converting streets, disused traffic triangles, parking lots and other under-utilized sites across the five boroughs into more than 300 new plazas and squares. To speed up their transformation, she began by designating the plazas with traffic cones, paint, and hauling in lawn chairs. Once the places became populated, potted trees, chairs, tables, and Wi-Fi were installed.

The best known of these projects was the series of new plazas along Broadway, taking advantage of the triangular spaces produced by the street's diagonal path. Making Times Square, one of the most heavily trafficked areas in the world, into a pedestrian mall was the program's main event. Along a 5-block area, from 42nd to 47th streets, the DOT designated multiple plazas. Their popularity with both locals and tourists improved pedestrian and driver safety, and higher commercial rents in the area prompted the city to hire the well-known Norwegian architectural firm Snoetta to redesign them as permanent spaces ${ }^{4}$. Since then, not all of these plazas have been well maintained or supported by City Hall. But the most successful made immediate differences in reducing crime, boosting local commerce, and improving street life. Bloomberg's commitment to public space was exceptional, however. Few American cities have high enough density or budgets to justify such large investments in public life.

As a result, numerous non-profits and other advocacy groups have stepped into this breach. In many cases, their concepts and proposals have filtered upwards to inform and shape city governments and planners' policy recommendations. Organizations such as the Project for Public Spaces, the Design Trust for Public Space, the Canadian Foundation for Indoor Public Spaces, and others across the country conduct research, sponsor design competitions, and publish books and websites to raise awareness and interest about public space among government officials, urban planners, and the general public. They can be seen as benevolent lobbyists for public spaces, often commissioning surveys and generating designs that cash-strapped city governments typically can't afford. Public space also plays an important role in larger organizations whose goal it is to transform the American built environment. The Congress for the New Urbanism, Making Cities Livable and Smart Growth America have each crafted their own versions of public space advocacy. Pedestrian spaces and public squares and plazas, often following traditional models are central elements in the CNU design principles, while Smart Growth America sponsors the Complete Streets program, which encourages municipalities to redesign streets to better accommodate pedestrians and bicyclists. Supplying municipal governments with detailed engineering and planning manuals makes it easy for cities to adopt their recommendations. They claim that these changes improve not only safety but also health, livability, and community cohesion ${ }^{5}$.

Another growing but very different approach to public space comes from artists and art organizations. Public art, public performances, social practice art, and "creative placemaking" all emphasize creative uses of public space without specifying form, duration or content. This has engendered an enormous range of artists' interventions into urban space, a category that can include everything from graffiti to government-commissioned art in public spaces. A new genre of art organization, such as New York's Creative Time, 
has emerged to support this approach. A well-funded non-profit, Creative Time sponsored artist Paul Chan's community-centered production of Waiting for Godot, performed in the middle of an intersection in New Orleans' flood devastated Ninth Ward. Another important work was feminist artist Suzanne Lacy's Between the Door and the Street. Lacy asked 400 people, mostly women, to sit on the stoops of a single block in Brooklyn and discuss gender issues for an afternoon. Thousands of people showed up to walk down the street and listen to their conversations ${ }^{6}$.

Smaller, less expensive and more concerned with the built environment are DIY (Do It Yourself) urban projects known as tactical urbanism or temporary urbanism. They also cover a vast range of activities, temporalities, and scale. The American pavilion at the 2012 Venice Biennale, Spontaneous Intervention: Design Actions for the Common Good, cataloged I 26 of these small, pop-up temporary and mobile interventions into urban public life, ranging from guerrilla gardening and yarn bombing, to free mini-libraries in phone booths and, most famously, Park(ing) Day, which encouraged anyone to turn a parking space into a temporary park. In many cases, ordinary people rather than designers or artists undertook these projects ${ }^{8}$.

Finally, designers have been enormous beneficiaries of all of these efforts. Although quick and inexpensive projects have received a lot of attention, more permanent public spaces require professional expertise. The increasing number of commissions for public parks, plazas, and other communal places has prompted many architects, urban designers and landscape architects to add public space design to their portfolios. These new opportunities also attracted European designers experienced in working on public projects. The Danish architect, Jan Gehl, whose firm specializes in urban public spaces, and who has written several books on the subject, recently opened offices in New York and San Francisco. The French landscape firm Agence Ter, working with local partners, just won an important competition to redesign Los Angeles' historic Pershing Square. All of these activities, ranging from amateur efforts such as yarn bombing to sophisticated professional park designs, have led public space advocates to assert that we live in a golden age of public space. Bicycle lanes, upgraded public plazas designed for human comfort, farmers markets and pedestrianized streets all demonstrate growing investments in high-quality urban spaces. Furthermore, new planning policies encourage sidewalk cafes, festivals and street performers, and more and more cities adopt "complete streets" programs. While not all of these advocates agree on every point, they all assert that "vibrant" public spaces are fundamental in humanizing contemporary cities, and cite the increasing number of people enjoying these spaces as evidence of their success.

Underlying the broad array of practices described above is an assumption that the goal of creating public spaces is to bring "everyone" together in safe and pleasant places. This, they argue, fosters social unity and supports democracy'. Important exceptions to this approach are critical artists such as Chan and Lacey. Their work is intended to do the opposite: to focus on specific social groups, such as African-Americans or women and to unsettle rather than comfort the users of public space.

\section{Questions about Pubic Space}

In spite of such apparent success, critics have challenged their aspirations toward inclusiveness and claims to appeal to the desires and values of a single unified public, 
arguing that these spaces have clear limits. This is particularly visible when we examine them in the American context. Focusing on central cities, they neglect the suburbs, where more than $50 \%$ of Americans live. Emphasizing pedestrians and bicyclists over cars, they privilege the young and able-bodied. Assuming that highly diverse populations are a single universal group of "users" without significant differences, they fail to consider and even mask the troubling social, racial and spatial inequalities that have long characterized the United States. Scholars have pointed out that there is no single "public" but a myriad of publics, each with differing identities and interests. Some publics, such as white men, claim powerful rights to urban space, while the claims of others, such as AfricanAmericans and the homeless are far weaker ${ }^{10}$. Public spaces invariably reflect these differences. Bloomberg's celebrated public spaces, for example have been criticized as primarily benefitting tourists and wealthy Manhattan residents. There are racial implications to approaches that assume a generic public, disregarding the fact that many whites automatically link the presence of blacks with danger and criminality. Studies have shown that sharing public spaces with more than a limited percentage of non-whites makes white people uncomfortable".

A more serious accusation is the contradiction between New York's new public plazas and squares and another signature Bloomberg public space initiative: "Stop and Frisk." Highly controversial, this policy allowed the New York Police Department to stop, question and search any "suspicious" pedestrian. In $201 \mathrm{I}$ alone, police stopped nearly 700,000 people, nearly all African-American or Latino males, essentially depriving them of equal rights to be in public ${ }^{12}$. Most of these stops occurred in neighborhoods far from those with newly improved public spaces. Across the country, the "Black Lives Matter" movement has demonstrated that African-American men are not safe in public, risking death from police or other members of the public as they conduct their daily lives. The fatal shooting of Travon Martin, a black teenager on the way to his mother's house, by a white neighbor who was acquitted of any crime was only one example of racially restricted access to space ${ }^{13}$.

Even the apparently benign complete streets movement can be seen as dangerously "incomplete", imposing privileged, usually white, narratives that drown out the voices of low-income and minority communities. Street vending, a largely immigrant economic activity, or Chicano low riding and other car-centered public activities are completely absent from their concept of street life. This bias has led African-American communities to organize against bike lanes in their neighborhoods, identifying hipster bikers as the first wave of gentrification ${ }^{14}$.

These critiques are important, and, as the Black Lives Matter movement shows, the stakes are high. By focusing on the popularity and "vibrancy" of a limited number of designated spaces, public space advocates and designers avoid very real issues of access, use and identity present in other kinds of public spaces. Often influenced by European examples, they ignore America's continuing problems of segregation and racial violence, assuming a spatial equality that in fact does not exist. In order for American public spaces to become truly public, both discourse and design need to confront their actual social content. This means acknowledging inequality and exclusion, conflict, and contestation. A more expansive view of public space would include protests such as the Occupy Movement and Black Lives Matter demonstrations, sidewalk livelihoods such as street vending and day labor, and even the presence of homeless people, whose domestic lives 
take place in public, on city streets. This definition of public space would be far more challenging than current versions, but ultimately more productive in connecting public spaces with real issues of democracy and citizenship.

\section{Notes}

(I) See, for example: Don Mitchell (2003), The Right to the City: Social Justice and the Fight for Public Space, New York: Routledge.

(2) See: http://www.gsa.gov/graphics/pbs/pmg_partl_intro.pdf, Accessed 7/28/16. And https://www.arts.gov/partnerships/creative-placemaking, accessed 7/28/16.

(3) William H. Whyte's book (1980) and film, The Social Life of Small Urban Spaces is a classic of public space design.

(4) http://www.pps.org/reference/broadway-boulevard-transforming-manhattans-most-famousstreet-to-improve-mobility-increase-safety-and-enhance-economic-vitality/. Accessed II/5/I4.

(5) http://www.smartgrowthamerica.org/complete-streets. Accessed 7/28/16.

(6) http://creativetime.org. Accessed 7/28/16.

(7) http://www.spontaneousinterventions.org/interventions

(8) www.architectmagazine.com/Design/spontaneous-interventions. Accessed 4/20/16

(9) http://gehlarchitects.com. Accessed 10/20/I5.

(10) Nancy Fraser (1990), "Rethinking the Public Sphere: A Contribution to the Critique of Actually Existing Democracy”, Social Text, No. 25/26, pp. 56-80.

(I I) See, for example: Dovidio, John F.; Gaertner, Samuel E.; Kawakami, Kerry; Hodson, Gordon (2002), "Why can't we just get along? Interpersonal biases and interracial distrust,", Cultural Diversity and Ethnic Minority Psychology, Vol 8(2), May, Pp. 88-I02.

(12) http://www.nytimes.com/interactive/2014/09/19/nyregion/stop-and-frisk-is-all-but-gone-fromnew-york.html? r=0. Accessed I I/I5/I4. On August II, 2013, Federal judge Shira Scheindlin declared that Bloomberg's "stop and frisk" policy was unconstitutional. http://www.nytimes.com/2013/08/I3/nyregion/stop-and-frisk-practice-violated-rights-judgerules.html?.pagewanted=all\& $r=0$. Accessed Nov. II, 2014.

(32) http://www.nytimes.com/interactive/2012/04/02/us/the-events-leading-to-the-shooting-oftrayvon-martin.html? $r=0$, Accessed 7/28/16.

(14) See Stephen Zavestoski and Julian Agyeman (eds.) (2014) Incomplete Streets, processes, practices, and possibilities, New York: Routledge. 